\title{
$\left(\mathbf{N a}^{+}+\mathbf{K}^{+}\right)$ATPase Inhibitors and Intracellular Electrolytes in Essential Hypertension
}

\author{
Taisuke Iwaoka, M.D.,* Charles A. Nugent, M.D.,** \\ Teruhisa UmedA, M.D., ${ }^{*}$ and Tatsuo SAto, M.D.*
}

\begin{abstract}
SUMmary
White blood cell (WBC) $\mathrm{Na}^{+}$and $\mathrm{K}^{+}$concentrations, plasma $\left(\mathrm{Na}^{+}+\right.$ $\left.\mathrm{K}^{+}\right)$ATPase inhibition and blood pressure were determined in normotensive control subjects and patients with essential hypertension. While the untreated hypertensive group had significantly lower $\mathrm{WBC} \mathrm{K}^{+}$concentrations than the normotensive group (mean \pm SEM, $121.6 \pm 4.4$ vs. $134.7 \pm$ $2.8 \mathrm{mEq} / \mathrm{kg}, \mathrm{p}<0.05)$, no significant difference was observed in $\mathrm{WBC} \mathrm{Na}^{+}$ concentrations between the 2 groups. The mean of plasma $\left(\mathrm{Na}^{+}+\mathrm{K}^{+}\right)$ATPase inhibition in untreated hypertensive patients was higher than that in normotensive controls $(14.8 \pm 1.7$ vs. $7.2 \pm 1.8 \%, \mathrm{p}<0.05)$. The correlations between $\left(\mathrm{Na}^{+}+\mathrm{K}^{+}\right)$ATPase inhibition and mean blood pressure and between $\mathrm{WBC} \mathrm{Na}^{+} / \mathrm{K}^{+}$ratio and mean blood pressure were significant ( $\mathrm{r}=0.278, \mathrm{p}<0.05$ and $0.270, \mathrm{p}<0.05$, respectively), but both were weak. However, untreated hypertensive patients with higher $\left(\mathrm{Na}^{+}+\right.$ $\left.\mathrm{K}^{+}\right)$ATPase inhibition had significantly higher $\mathrm{WBC} \mathrm{Na}^{+} / \mathrm{K}^{+}$ratios than untreated patients with less $\left(\mathrm{Na}^{+}+\mathrm{K}^{+}\right)$ATPase inhibition. These results suggest a contribution of plasma $\left(\mathrm{Na}^{+}+\mathrm{K}^{+}\right)$ATPase inhibition in the production of high blood pressure in a subset of patients with essential hypertension, which results in altered intracellular $\mathrm{K}^{+}$concentrations.
\end{abstract}

\section{Additional Indexing Words:}

White blood cell sodium concentration White blood cell potassium concentration Plasma $\left(\mathrm{Na}^{+}+\mathrm{K}^{+}\right)$ATPase inhibitor Pathogenesis of hypertension

\footnotetext{
A

BNORMALITIES of intracellular electrolyte concentrations have been shown in patients with essential hypertension. ${ }^{1-5)}$ Blaustein ${ }^{6)}$ proposed that an increased intracellular $\mathrm{Na}^{+}$concentration in arteriolar smooth muscle cell caused, by way of $\mathrm{Na}^{+}-\mathrm{Ca}^{++}$interchange, a rise in intracellular free $\mathrm{Ca}^{++}$concentration of arteriolar smooth muscle fibers. They further hypothesized that this was responsible for increased contraction of arteriolar

From the Third Department of Internal Medicine,* Kumamoto University Medical School, Kumamoto, Japan and the Endocrine Section,** Department of Internal Medicine, VA Medical Center and the University of Arizona College of Medicine, Tucson, Arizona, U.S.A.

Address for reprint: Taisuke Iwaoka, M.D., Third Department of Internal Medicine, Kumamoto University Medical School, Honjyo 1-1-1, Kumamoto 860, Japan.

Received for publication December 1, 1986.
} 
muscle. This theory received substantial support in the observation ${ }^{7)}$ that there was a striking correlation between intracellular free $\mathrm{Ca}^{++}$concentration and blood pressure in human platelets. On the other hand, de Wardener et $\mathrm{al}^{8)}$ postulated that sodium-loading or impairment of renal excretion of sodium led to the production of a humoral substance that inhibits $\left(\mathrm{Na}^{+}+\mathrm{K}^{+}\right)$ATPase, thus increasing renal sodium excretion. Hamlyn et $\mathrm{al}^{9)}$ reported a significant correlation between systemic blood pressure in either normal subjects or patients with essential hypertension and activity of an inhibitor of $\left(\mathrm{Na}^{+}+\mathrm{K}^{+}\right)$ATPase in their boiled plasma. In the present study, we determined activity of plasma $\left(\mathrm{Na}^{+}+\mathrm{K}^{+}\right)$ATPase inhibitors in boiled plasma of normal subjects and patients with essential hypertension and examined its correlation with blood pressure and with the intracellular concentration of sodium and potassium in leukocytes.

\section{Materials and Methods}

\section{Subjects:}

The population of patients with essential hypertension included 26 on no drug treatment, 16 treated with $50 \mathrm{mg}$ of hydrochlorothiazide (HCT) per day and 20 treated with $50 \mathrm{mg}$ of HGT and 16 to $20 \mathrm{mmol}$ of potassium chloride per day. We also studied 34 normotensive (blood pressure $<140 /$ $90 \mathrm{mmHg}$ ) control subjects who were not taking diuretics, digitalis or its derivatives, antihypertensive drugs or other drugs known to affect blood pressure or electrolyte metabolism. All of the patients and control subjects were males. Hypertension was defined as a systolic pressure greater than $160 \mathrm{mmHg}$ and/or a diastolic pressure greater than $95 \mathrm{mmHg}$. This study was approved by the University of Arizona Human Studies Committee and all patients gave their informed consent.

\section{Collection of samples:}

The patients and normal subjects came to the clinic in the morning after an overnight fast. Blood pressure in the right arm was measured using an automatic sphygmomanometer (Sentry, Automatic Screening Devices, Inc., Costa Mesa, CA, USA) after the patient had been sitting for $5 \mathrm{~min}$. Samples of $10 \mathrm{ml}$ of blood in heparin (143 IU of heparin per $10 \mathrm{ml}$ ) and $5 \mathrm{ml}$ of blood in ethylenediaminetetraacetic acid (EDTA $7.2 \mathrm{mg}$ per $5 \mathrm{ml}$ ) were obtained. Heparinized blood was used immediately for the measurement of white blood cell (WBC) $\mathrm{Na}^{+}$and $\mathrm{K}+$ concentrations. EDTA plasma was promptly centrifuged at $4^{\circ} \mathrm{C}$ and stored at $-20^{\circ} \mathrm{C}$ for determination of $\left(\mathrm{Na}^{+}\right.$ $+\mathrm{K}^{+}$) ATPase inhibition and plasma renin activity (PRA). Information on 
age, height, weight and family history of hypertension was recorded for each patient. A family history was regarded as positive if there was a history of hypertension in at least one parent, sibling or child.

\section{Measurement of $W B C \mathrm{Na}^{+}$and $K^{+}$concentrations:}

WBC Na+ and $\mathrm{K}^{+}$determinations were performed at $22^{\circ} \mathrm{C}$ using a modification of the method of Baron and Ahmed. ${ }^{10)}$ A $10 \mathrm{ml}$ sample of heparinized blood was mixed gently in a plastic syringe with $2.5 \mathrm{ml}$ of $6 \%$ dextran (average molecular weight 200,000 to 300,000, Baker Chemical Co., Phillipsburg, NJ, USA) in an isotonic solution of Hanks salts with 1-glutamine, pH 7.4 (M-199, Gibco Laboratories, Santa Clara, CA, USA) and was sedimented for $35 \mathrm{~min}$ at an angle of $45^{\circ}$. The supernatant was centrifuged at $160 \mathrm{~g}$ for $10 \mathrm{~min}$. The supernatant was discarded. Using a pipette, the sediment was resuspended gently in $3 \mathrm{ml}$ of distilled water for $10 \mathrm{sec}$ to lyse residual erythrocytes and the osmolarity promptly restored to normal by adding $1 \mathrm{ml}$ of a 4 times concentrated M-199 solution. The resuspended WBC were centrifuged for $10 \mathrm{~min}$ at $160 \mathrm{~g}$, the supernatant removed with suction and $1.1 \mathrm{ml}$ of $5 \%$ glucose containing $2 \%$ bovine serum albumin (BSA) (Sigma Chemical Co., St. Louis, MO, USA) plus about $0.5 \mu \mathrm{Ci}$ of ${ }^{125}$ I-BSA (ICN, Irvine, CA, USA) were added to the sediment. After pipetting, $1 \mathrm{ml}$ of suspension was transferred to a preweighed $1.5 \mathrm{ml}$ polypropylene microcentrifuge tube (Robbins Scientific Go., Mountain View, CA, USA) and centrifuged at $160 \mathrm{~g}$ for $10 \mathrm{~min}$. One tenth $\mathrm{ml}$ of the supernatant was removed and diluted with $9.9 \mathrm{ml}$ of distilled water for measurement of sodium and potassium using emission flame photometry (Perkin Elmer 603, Atomic Absorption Spectrophotometer, USA). Another $0.1 \mathrm{ml}$ of supernatant was removed and used for counting ${ }^{125} \mathrm{I}$. The remaining supernatant was aspirated and discarded. The microcentrifuge tube with its contained plug of cells was weighed and the ${ }^{125} \mathrm{I}$ activity counted.

After the ${ }^{125} \mathrm{I}$ in the tube containing the pellet was counted, $0.1 \mathrm{ml}$ of concentrated nitric acid low in sodium ("Ultrex", Baker Chemical Co., Phillipsburg, NJ, USA) was added and the pellet digested for $90 \mathrm{~min}$ at $70^{\circ} \mathrm{C}$ in a water bath. After dilution with $9.9 \mathrm{ml}$ of distilled water, $\mathrm{Na}^{+}$and $\mathrm{K}^{+}$ were measured by emission flame photometry. The intracellular concentrations of $\mathrm{Na}^{+}$was calculated as follows:

$$
\frac{\left[\mathrm{Na}^{+}\right]_{\mathrm{p}}-\left\{\left[\mathrm{Na}^{+}\right]_{\mathrm{s}} \times \mathrm{ECF}(\%) \times 10^{-4}\right\}}{[\mathrm{Wt}]_{\mathrm{p}} \times[100-\mathrm{ECF}(\%)\} \times 10^{-6}}(\mathrm{mEq} / \mathrm{kg} \text { of wet cell weight })
$$

Where $\left[\mathrm{Na}^{+}\right]_{\mathrm{p}}$ was the $\mathrm{Na}^{+}$concentration in the pellet $(\mathrm{mEq} / 1),\left[\mathrm{Na}^{+}\right]_{\mathrm{s}}$ was the $\mathrm{Na}^{+}$concentration in the supernatant $(\mathrm{mEq} / 1),[\mathrm{Wt}]_{\mathrm{p}}$ was the weight 
of the pellet (mg) and $\operatorname{ECF}(\%)$ was the percentage of extracellular fluid volume in the pellet. The $\mathrm{WBC}^{+}$concentration was obtained in the same way. Both intraassay and interassay variances for $\mathrm{WBC} \mathrm{Na}^{+}$and $\mathrm{WBC} \mathrm{K}^{+}$ concentration were less than $5 \%$.

Measurement of plasma $\left(\mathrm{Na}^{+}+K^{+}\right)$ATPase inhibition:

A modification of the method of Hamlyn et al ${ }^{19}$ was used. In the original method the assay was initiated by rapidly mixing in a cuvette a small volume of the enzyme with the reaction cocktail containing the sample (boiled plasma supernatant). A recording spectrophotometer was used to follow the decrease in absorbance at $340 \mathrm{~nm}$ due to oxidation of NADH. In our case, a $50 \mu \mathrm{l}$ aliquot of a solution of dog kidney $\left(\mathrm{Na}^{+}+\mathrm{K}^{+}\right)$ATPase $(1.2 \mu \mathrm{g}$ protein) (Sigma Ghemical Co., St. Louis, MO, USA) was added to the cuvette containing $125 \mu \mathrm{l}$ of control solution $(120 \mathrm{mM} \mathrm{NaCl}, 2.1 \mathrm{mM} \mathrm{KCl}, 2.8$ $\mathrm{mM}$ EDTA, $1.2 \mathrm{mM} \mathrm{MgSO} \cdot \cdot 7 \mathrm{H}_{2} \mathrm{O}, 2.5 \mathrm{mM} \mathrm{CaSO}_{4}, 1.2 \mathrm{mM} \mathrm{K} \mathrm{HPO}_{4}$, $26 \mathrm{mM} \mathrm{NaHCO}_{3}$ and $3.4 \mathrm{mM} \mathrm{EGTA}$ ) and $125 \mu \mathrm{l}$ of reaction cocktail (106.7 $\mathrm{mM}$ TES-Tris, $266.7 \mathrm{mM} \mathrm{NaCl}, 53.3 \mathrm{mM} \mathrm{KGl,} 17.9 \mathrm{mM}$ EGTA, $24 \mathrm{mM}$ $\mathrm{MgSO}_{4} \cdot 7 \mathrm{H}_{2} \mathrm{O}, 5.3 \mathrm{mM} \mathrm{CaCl}_{2}, 3.2 \mathrm{U} / \mathrm{ml} \mathrm{PK}, 3.2 \mathrm{U} / \mathrm{ml} \mathrm{LDH}, 8.0 \mathrm{mM}$ ATP,

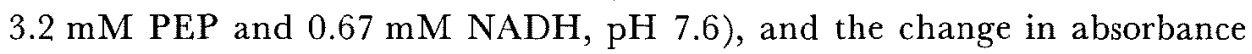
was recorded for $4 \mathrm{~min}$ by a spectrophotometer (Beckman model $25 \mathrm{Spec}$ trophotometer, USA). The slope of this trace between $1.5 \mathrm{~min}$ and $3.5 \mathrm{~min}$ was designated as slope I. Then, after $200 \mu 1$ of control solution or boiled plasma supernatant was added and mixed, slope II was obtained (timing same as in the case of slope I). This plasma supernatant was obtained by boiling for 5 min after adjustment of plasma $\mathrm{pH}$ to 5.5 with $1 \mathrm{~N} \mathrm{HCl}$, followed by centrifugation at $30,000 \mathrm{~g}$ for $30 \mathrm{~min}$ at $4^{\circ} \mathrm{C}$. The interassay coefficients of variation obtained using this modification were $3.8 \%$ and $3.2 \%$ with sodium vanadate (Fisher Scientific Co., Fair Lawn, NJ, USA) standards of $0.25 \times 10^{-6} \mathrm{M}$ and $0.5 \times 10^{-6} \mathrm{M}$, respectively. These concentrations of vanadate were the concentrations in $200 \mu \mathrm{l}$ volumes of control solution added to the cuvette to obtain slope II. The intraassay coefficients of variation were $1.9 \%$ and $1.8 \%(n=8)$ using the same concentrations of $\mathrm{Na}_{3} \mathrm{VO}_{4}$. These coefficients of variation were one-third of the values obtained with the original method. One reason for the decrease in variance may be attributable to the insolubility of the enzyme. Because this enzyme is membrane bound, suspensions may not be homogenous even after thorough mixing. Thus, $50 \mu$ aliquot of the suspensions may not contain the same amount of enzyme. Another problem minimized by this modification is the effect of a gradual decrease in activity of the enzyme during a series of assays, even though the tube of enzyme suspension is stored in an ice bath and is mixed 
briefly just before use. In this modification, each tube is used as its own control and this may account for the lower variance of the result.

\section{Other assays:}

PRA was measured using an Angiotensin I kit (New England Nuclear, Boston, MA, USA).

\section{Statistics:}

All results are expressed as the mean \pm SEM. Analysis of variance was used to examine differences between groups. When differences significant at the $p<0.05$ level were found, Fisher's least significant difference test was used to identify pairs of groups that were significantly different at the $p<0.05$ level.

\section{Results}

The mean plasma $\left(\mathrm{Na}^{+}+\mathrm{K}^{+}\right)$ATPase inhibition in patients with untreated essential hypertension was higher than in normotensive subjects $(14.6 \pm 1.67$ vs. $7.2 \pm 1.76 \%, p<0.05$, Fig. 1). The presence of a family history of hypertension was not associated with significant differences in $\left(\mathrm{Na}^{+}+\mathrm{K}^{+}\right)$ATPase in either normotensive subjects or untreated hypertensive patients.

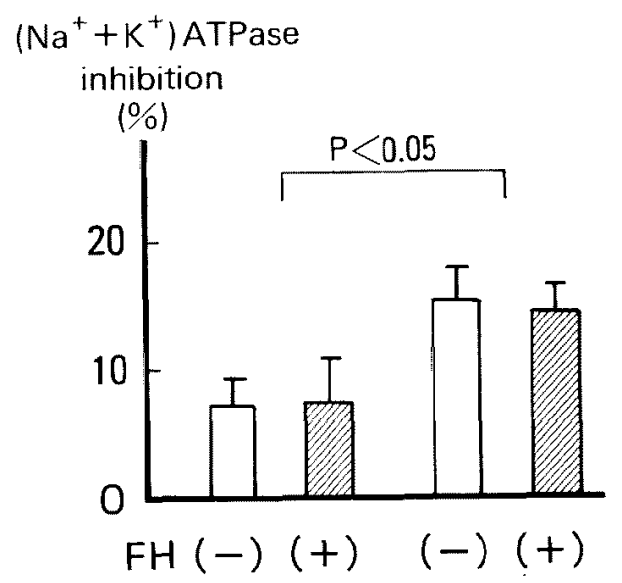

Normotensive Hypertensive subjects patients

Fig. 1. Mean percent ( \pm SEM) of plasma $\left(\mathrm{Na}^{+}+\mathrm{K}^{+}\right)$ATPase inhibition in normotensive subjects and untreated patients with essential hypertension. FH denotes family history of hypertension. 
Table I. Results in Different

\begin{tabular}{cl|c|c|c}
\hline & & $\begin{array}{c}\text { Age } \\
\text { (year) }\end{array}$ & $\begin{array}{c}\text { Weight } \\
(\mathrm{kg})\end{array}$ & $\begin{array}{c}\text { Mean BP } \\
(\mathrm{mmHg})\end{array}$ \\
\hline \multirow{2}{*}{ NT } & FH (-) & $64.1(27) \pm 1.9$ & $76.0(27) \pm 2.3$ & $95.4(27) \pm 1.3$ \\
& FH (+) & $53.6(7) \pm 4.8$ & $83.2(7) \pm 3.2$ & $94.5(7) \pm 1.7$ \\
& Total & $61.9(34) \pm 2.0$ & $77.5(34) \pm 2.0$ & $95.2(34) \pm 1.1$ \\
\hline & FH (-) & $61.2(11) \pm 2.1$ & $91.2(11) \pm 4.7$ & $121.9(11) \pm 2.1$ \\
EH & FH (+) & $59.0(15) \pm 2.5$ & $87.4(15) \pm 4.4$ & $119.4(15) \pm 1.7$ \\
& Total & $59.9(26) \pm 1.7$ & $89.0(26) \pm 3.2$ & $120.4(26) \pm 1.4$ \\
\hline HCT & FH (-) & $64.3(10) \pm 3.6$ & $76.3(10) \pm 5.5$ & $95.7(10) \pm 2.7$ \\
& Total & $56.2(6) \pm 2.2$ & $87.0(6) \pm 5.4$ & $100.9(6) \pm 2.6$ \\
HCT & FH (-) & $61.3(16) \pm 2.6$ & $80.3(16) \pm 4.0$ & $97.6(16) \pm 2.1$ \\
KCl & FH (+) & $62.8(13) \pm 1.3$ & $79.0(13) \pm 4.2$ & $100.6(13) \pm 2.4$ \\
& Total & $62.6(7) \pm 2.2$ & $84.7(7) \pm 1.7$ & $102.4(7) \pm 4.0$ \\
& & $62.7(20) \pm 1.1$ & $81.0(20) \pm 2.9$ & $101.3(20) \pm 2.1$
\end{tabular}

* Results are expressed as mean \pm SEM with figures in parentheses denoting number studied. NT means normotensive, EH patients with essential hypertension taking no antihypertensive drugs,

There was no significant difference in $\mathrm{WBC} \mathrm{Na}^{+}$concentration between normotensive control subjects and patients with untreated hypertension. WBC $\mathrm{K}^{+}$concentration was significantly lower $(\mathrm{p}<0.05)$ in untreated hypertensive patients than in normal subjects (Table I, Fig. 2). Untreated hypertensive patients with a family history of hypertension also had higher WBC Na+ and lower WBC $\mathrm{K}^{+}$than those without a family history of hypertension (Fig. 2).
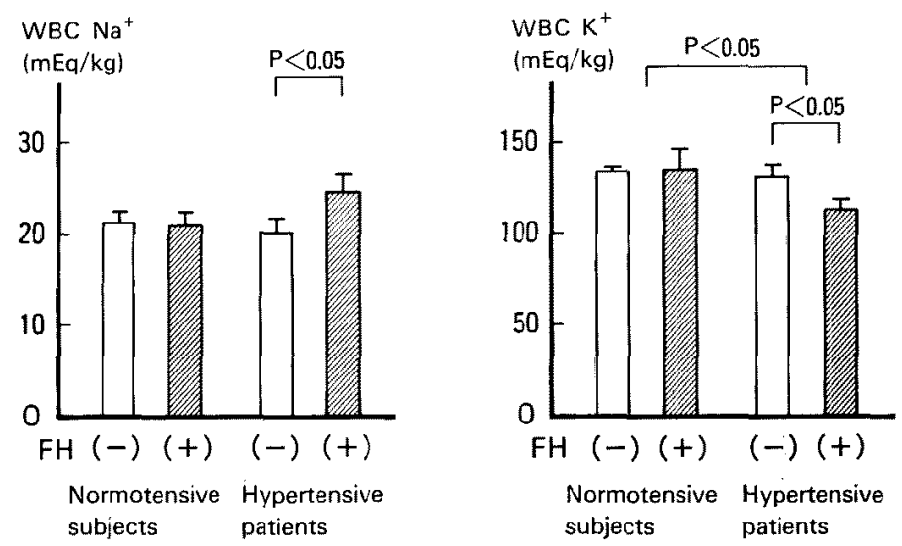

Fig. 2. Mean ( \pm SEM) WBC $\mathrm{Na}^{+}$(left) and $\mathrm{K}^{+}$(right) concentrations in normotensive subjects and untreated patients with essential hypertension. FH denotes family history of hypertension. 
Diagnostic Groups*

\begin{tabular}{|c|c|c|c}
\hline $\begin{array}{c}\text { WBC Na+} \\
(\mathrm{mEq} / \mathrm{kg})\end{array}$ & $\begin{array}{c}\text { WBC K+ } \\
(\mathrm{mEq} / \mathrm{kg})\end{array}$ & $\begin{array}{c}\text { WBC } \\
\left(\mathrm{Na}^{+} / \mathrm{K}^{+}\right)\end{array}$ & $\begin{array}{c}\text { ATPase inhibition } \\
\left(\mathrm{Na}^{+}+\mathrm{K}^{+}\right)\end{array}$ \\
\hline $21.4(27) \pm 0.7$ & $134.3(27) \pm 2.3$ & $0.161(27) \pm 0.007$ & $7.2(24) \pm 1.9$ \\
$21.3(7) \pm 1.1$ & $136.8(7) \pm 9.9$ & $0.162(7) \pm 0.015$ & $7.2(7) \pm 3.5$ \\
$21.3(34) \pm 0.6$ & $134.7(34) \pm 2.8$ & $0.162(34) \pm 0.007$ & $7.2(31) \pm 1.7$ \\
\hline $20.4(11) \pm 1.4$ & $131.7(11) \pm 6.1$ & $0.164(11) \pm 0.019$ & $15.1(11) \pm 2.5$ \\
$24.9(13) \pm 1.5$ & $113.0(13) \pm 5.1$ & $0.233(13) \pm 0.023$ & $14.2(15) \pm 2.2$ \\
$22.8(24) \pm 1.1$ & $121.6(24) \pm 4.4$ & $0.201(24) \pm 0.017$ & $14.6(26) \pm 1.7$ \\
\hline $21.4(10) \pm 1.7$ & $126.1(10) \pm 6.9$ & $0.178(10) \pm 0.019$ & $9.7(8) \pm 4.9$ \\
$20.0(6) \pm 2.0$ & $122.5(6) \pm 8.8$ & $0.175(6) \pm 0.030$ & $17.0(6) \pm 3.9$ \\
$20.9(16) \pm 1.3$ & $124.8(16) \pm 5.5$ & $0.177(16) \pm 0.017$ & $12.8(14) \pm 3.2$ \\
\hline $17.5(13) \pm 1.1$ & $140.7(13) \pm 3.5$ & $0.125(13) \pm 0.008$ & $10.8(11) \pm 2.8$ \\
$20.6(7) \pm 1.4$ & $127.6(7) \pm 7.9$ & $0.168(7) \pm 0.017$ & $19.1(5) \pm 2.6$ \\
$18.6(20) \pm 0.9$ & $136.2(20) \pm 3.8$ & $0.140(20) \pm 0.009$ & $13.4(16) \pm 2.4$ \\
\hline
\end{tabular}

and HCT and HCT $+\mathrm{KCl}$ EH patients taking hydrochlorothiazide alone or with $\mathrm{KCl}$, respectively.

The correlations between $\left(\mathrm{Na}^{+}+\mathrm{K}^{+}\right)$ATPase inhibition and mean blood pressure and between the $\mathrm{WBC} \mathrm{Na}^{+} / \mathrm{K}+$ ratio and mean blood pressure were $0.278(\mathrm{p}<0.05, \mathrm{n}=58)$ and $0.270(\mathrm{p}<0.05, \mathrm{n}=58)$, respectively (Fig. 3). In normotensive subjects and untreated hypertensive patients, the WBC $\mathrm{Na}^{+} / \mathrm{K}^{+}$ratio was not significantly correlated with $\left(\mathrm{Na}^{+}+\mathrm{K}^{+}\right)$ATPase inhibition. However, the $\mathrm{WBC} \mathrm{Na}^{+} / \mathrm{K}^{+}$ratio in untreated hypertensive patients with high $\left(\mathrm{Na}^{+}+\mathrm{K}^{+}\right)$ATPase inhibition (more than 15\%) and with low $\left(\mathrm{Na}^{+}+\mathrm{K}^{+}\right)$ATPase inhibition (less than $15 \%$ ) were $0.24 \pm 0.023$
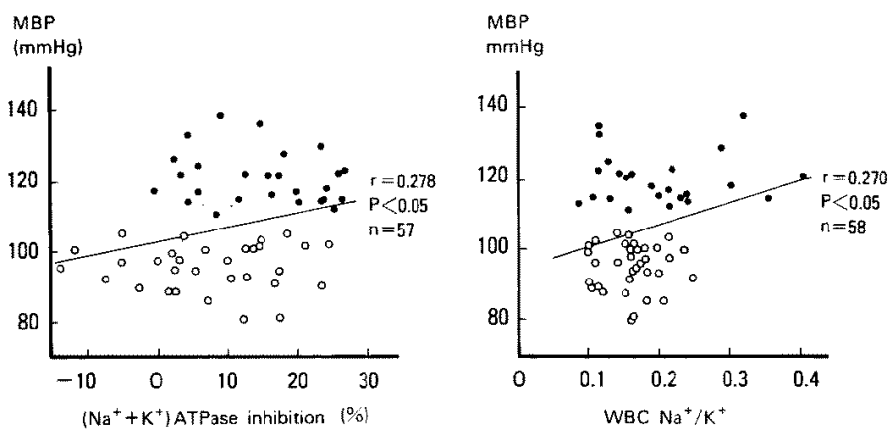

Fig. 3. Mean blood pressure in $\mathrm{mmHg}$ is plotted as a function of percent plasma $\left(\mathrm{Na}^{+}+\mathrm{K}^{+}\right)$ATPase inhibition (left) and as a function of the WBC $\mathrm{Na}^{+} / \mathrm{K}^{+}$ratio (right) in normotensive subjects (open circles) and in untreated patients with essential hypertension (solid circles). 


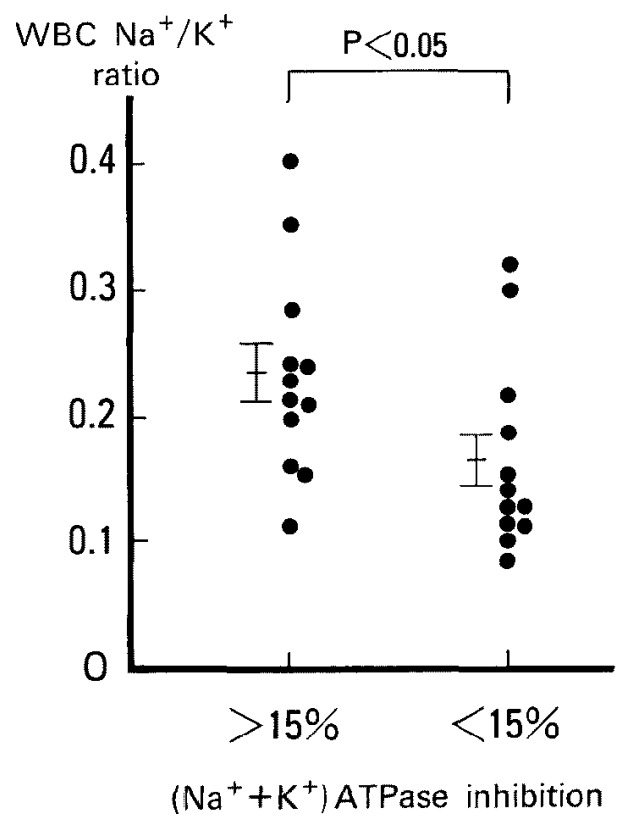

Fig. 4. The $\mathrm{WBC} \mathrm{Na}^{+} / \mathrm{K}^{+}$ratio in untreated hypertensive patients with plasma $\left(\mathrm{Na}^{+}+\mathrm{K}^{+}\right)$ATPase inhibition greater or less than $15 \%$.
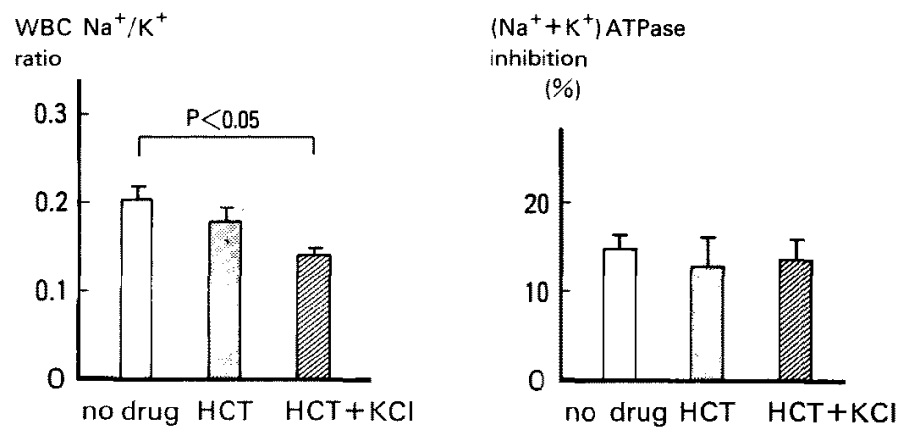

Fig. 5. Mean ( \pm SEM) WBC Na $+K+$ ratio (left) and mean $( \pm S E M)$ percent of plasma $\left(\mathrm{Na}^{+}+\mathrm{K}^{+}\right) \mathrm{ATPase}$ inhibition (right) in hypertensive patients on no drug, hydrochlorothiazide (HCT) and HCT plus potassium chloride (KCl).

$(\mathrm{n}=12)$ and $0.17 \pm 0.022(\mathrm{n}=12)$, respectively, $\mathrm{p}<0.05$ (Fig. 4).

The $\mathrm{WBG} \mathrm{Na}^{+} / \mathrm{K}^{+}$ratio in patients treated with $\mathrm{HCT}$ alone tended to be lowered, but was not significantly different from patients with untreated hypertension. However, the mean $\mathrm{WBC} \mathrm{Na}^{+} / \mathrm{K}+$ ratio was significantly lower in patients treated with $\mathrm{HCT}$ plus $\mathrm{KCl}$ than in untreated hypertensive patients (Fig. 5). On the other hand, the mean $\left(\mathrm{Na}^{+}+\mathrm{K}^{+}\right)$ATPase inhibi- 


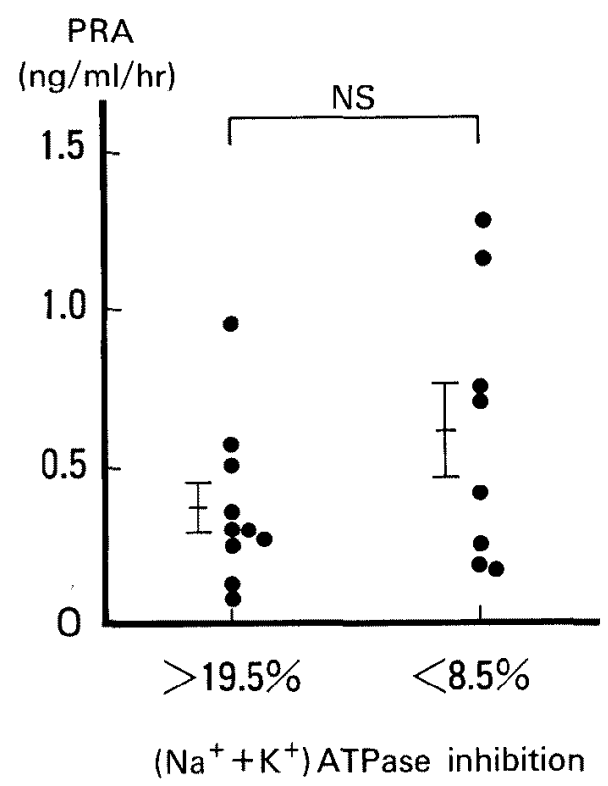

Fig. 6. Plasma renin activity in untreated patients with plasma $\left(\mathrm{Na}^{+}+\right.$ $\mathrm{K}^{+}$)ATPase inhibition greater than $19.5 \%$ or less than $8.5 \%$.

tion in the drug treated hypertensive patients was similar to that of untreated hypertensive patients (Fig. 5).

The PRA in a group of 8 untreated hypertensive patients with low $\left(\mathrm{Na}^{+}+\mathrm{K}^{+}\right)$ATPase inhibition (less than $8.5 \%$ ) was $0.60 \pm 0.15 \mathrm{ng} / \mathrm{ml} / \mathrm{hr}$, while activity in 10 untreated hypertensive patients with high $\left(\mathrm{Na}^{+}+\mathrm{K}^{+}\right)$ ATPase inhibition (more than 19.5\%) was $0.36 \pm 0.08 \mathrm{ng} / \mathrm{ml} / \mathrm{hr}$. This difference in PRA values was not statistically significant (Fig. 6). Finally, the body weight of patients with untreated hypertension was greater than that of normotensive control patients $(\mathrm{p}<0.01)$ but there was no significant correlation of body weight with $\left(\mathrm{Na}^{+}+\mathrm{K}^{+}\right)$ATPase inhibition.

\section{Discussion}

We found that the $\left(\mathrm{Na}^{+}+\mathrm{K}^{+}\right)$ATPase inhibition evoked by plasma from patients with untreated hypertension was significantly higher than that in plasma of normal subjects. This corroborates the report of Hamlyn et al. ${ }^{9)}$ Fifty-four percent of patients with untreated essential hypertension had plasma $\left(\mathrm{Na}^{+}+\mathrm{K}^{+}\right)$ATPase inhibition above $15 \%$; this was true in $23 \%$ of normotensive controls. This difference was significant by a Chi-square test $(p<0.02)$. Consequently, the correlation of plasma $\left(\mathrm{Na}^{+}+\mathrm{K}^{+}\right)$ATPase inhibition with mean blood pressure in these patients and control subjects 
was significant, but weak. Devynck et al ${ }^{11)}$ also determined sodium pump inhibition by interference with ouabain binding. They found that the digitalis-like factor was elevated in two-thirds of untreated hypertensive patients. However, as in our study, the increase was not consistent across patients. In addition, the overlap of $\mathrm{WBC} \mathrm{Na}{ }^{+} / \mathrm{K}^{+}$ratio of hypertensive patients and normotensive controls was consistent with our observation that approximately half of patients with essential hypertension did not have elevated levels of $\left(\mathrm{Na}^{+}+\mathrm{K}^{+}\right)$ATPase inhibitors in their plasma. However, the untreated hypertensive patients with high plasma $\left(\mathrm{Na}^{+}+\mathrm{K}^{+}\right)$ATPase inhibition had a significantly higher mean $\mathrm{WBC} \mathrm{Na}{ }^{+} / \mathrm{K}^{+}$ratio than patients with low plasma $\left(\mathrm{Na}^{+}+\mathrm{K}^{+}\right)$ATPase inhibition. These observations are compatible with the hypothesis that elevated $\left(\mathrm{Na}^{+}+\mathrm{K}^{+}\right)$ATPase inhibitors in plasma may contribute to essential hypertension in a subset of patients by altering the intracellular $\mathrm{Na}^{+}$and $\mathrm{K}^{+}$concentrations.

Burris et $\mathrm{al}^{12)}$ observed that ouabain sensitive ${ }^{86} \mathrm{Rb}$ uptake by the arterial wall of rats was depressed by the addition of plasma from hypertensive patients to the medium. This effect was more pronounced with plasma from patients with low renin essential hypertension than normal renin essential hypertension. Edmondson et $\mathrm{al}^{13}$ ) observed a significant correlation between the rate constant for glycoside-sensitive leucocyte sodium efflux during normal diet and the plasma concentrations of angiotensin II during a low sodium diet. We measured PRA in hypertensive patients with unrestricted sodium intake and found that PRA did not differ significantly as a function of plasma $\left(\mathrm{Na}^{+}+\mathrm{K}^{+}\right)$ATPase inhibition. On the other hand, Pedrinelli et $a^{14)}$ reported that there were no significant differences in forearm vascular responses to norepinephrine and/or ouabain infusion between hypertensive patients with low PRA and normal PRA. This casts doubt on the possibility of linking the development of human low renin hypertension to an endogenous $\left(\mathrm{Na}^{+}+\mathrm{K}^{+}\right)$ATPase inhibitor. Thus, the characteristics of the subgroup of patients with essential hypertension and high $\left(\mathrm{Na}^{+}+\mathrm{K}^{+}\right)$ATPase inhibition is unclear.

Antihypertensive treatment, especially diuretics and sodium chloride restriction, have been reported to alter the intracellular electrolyte composition. ${ }^{3,14}$ We found that $\mathrm{HCT}$ decreased the $\mathrm{WBC} \mathrm{Na}^{+} / \mathrm{K}^{+}$ratio and that this ratio was further decreased by $\mathrm{KCl}$ supplementation. However, neither HCT alone nor HCT plus KCl significantly altered the level of $\left(\mathrm{Na}^{+}\right.$ $\left.+\mathrm{K}^{+}\right)$ATPase inhibition. It has been shown that in vitro $\left(\mathrm{Na}^{+}+\mathrm{K}^{+}\right)$ATPase activity can be activated by potassium. Thus, the hypotensive effect of potassium in essential hypertension may reflect an activation of $\left(\mathrm{Na}^{+}+\mathrm{K}^{+}\right)$ATPase that compensates for elevated levels of an endogenous $\left(\mathrm{Na}^{+}+\mathrm{K}^{+}\right)$ATPase 
inhibitor. ${ }^{15)}$

\section{REFERENGES}

1. Tobian L, Binion JT: Tissue cations and water in hypertension. Circulation 5: 754, 1952

2. Edmondson RPS, Thomas RD, Hilton PJ, Patrick J: Abnormal leucocyte composition and sodium transport in essential hypertension. Lancet 1: 1003, 1975

3. Araoye MA, Khatri IM, Yao LL, Freis ED: Leukocyte intracellular cations in hypertension: effect of antihypertensive drugs. Am Heart J 96: 731, 1978

4. Ambrosioni E, Tartagni F, Montebugnoli L, Magnani B: Intralymphocytic sodium in hypertensive patients: a significant correlation. Clin Sci 57: 325s, 1979

5. Blaustein MP: Sodium transport and hypertension. Hypertension 6: 445, 1984

6. Blaustein MP: Sodium ions, calcium ions, blood pressure regulation and hypertension: a reassessment and hypothesis. Am J Physiol 232: c165, 1977

7. Erne P, Bolli P, Burgisser E, Buhler FR: Correlation of platelet calcium with blood pressure. Effect of antihypertensive therapy. New Engl J Med 310: 1084, 1984

8. de Wardener HE, MacGregor GA: The role of a circulating inhibitor of $\mathrm{Na}^{+}-\mathrm{K}^{+}-\mathrm{ATP}$ ase in essential hypertension. Am J Nephrol 3: 88, 1983

9. Hamlyn JM, Ringel R, Schaeffer J, Levinson PD, Hamilton BP, Kowarski AA, Blaustein MP: A circulating inhibitor of $\left(\mathrm{Na}^{+}+\mathrm{K}^{+}\right) \mathrm{ATPase}$ associated with essential hypertension. Nature 300: 650,1982

10. Baron DN, Ahmed SA: Intracellular concentration of water and of the principal electrolytes determined by analysis of isolated human leucocytes. Clin Sci 37: 205, 1969

11. Devynck MA, Pernollet MG, Rosenfeld JB, Meyer P: Measurement of digitalis-like compound in plasma: application in studies of essential hypertension. Br Med J 287: 63I, 1983

12. Burris JF, Pamnani MB, Hout SJ, Jemionek JF, Freis ED, Haddy FJ: Sodium-potassium (Na-K) pump activity in low renin essential hypertension. Clin Res 30: 733, 1982

13. Edmondson RPS, MacGregor GA: Leucocyte cation transport in essential hypertension: its relation to the renin-angiotensin system. Br Med J 282: 1267, 1981

14. Pedrinelli R, Taddei S, Graziadei L, Salretti A: Vascular responses to ouabain and norepinephrine in low and normal renin hypertension. Hypertension 8: 786, 1986

15. de Wardener HE, MacGregor GA: The relation of a circulating sodium transport inhibitor (the natriuretic hormone?) to hypertension. Medicine 62: 310, 1983 